\title{
Effectiveness of Cratylia argentea as an animal feed supplement in the control of gastrointestinal nematodes in sheep
}

\section{Eficácia de Cratylia argentea como suplemento alimentar animal no controle das nematodioses gastrointestinais em ovinos}

\author{
Manoel Eduardo da Silva ${ }^{1 *}$; Jackson Victor de Araújo ${ }^{2}$; \\ Wendeo Ferreira da Silveira ${ }^{3}$; Lorendane Millena de Carvalho ${ }^{4}$; Raul Rio Ribeiro
}

\begin{abstract}
Gastrointestinal nematodes are considered one of the most important sanitary problems affecting ruminants globally; whether parasitizing alone or acting with other pathogens, they are responsible for severe economic losses related to animal husbandry. Endoparasites in small ruminants are usually controlled with anti-helminthic drugs. However, certain strains of endoparasites are resistant to such drugs. Supplementation of the diet with protein-rich foods is one strategy for reducing the negative impact of gastrointestinal parasites. Cratylia argentea has anthelmintic properties and other characteristics that favor its use as an animal feed supplement. In the present study, we subdivided crossbred lambs into homogeneous groups and fed them C. argentea (G1), C. argentea plus Brachiaria spp. (G2), or Brachiaria spp. (G3) only. The animals in group G1 had a lower average number of eggs per gram of feces $(E P G)$ at Day $42(\mathrm{p}<0.05)$, and the average count was ten times lower than that in the control at the last evaluated time-point (Day 56). The animals exhibited linear weight gain, and those in group G1 gained the most weight. The combined use of drugs and plants containing bioactive compounds can minimize the evolution of multidrug resistance, prolonging the efficacy of the drugs. The FAMACHA ${ }^{\circledR}$ score showed little variation during the experiment $(\mathrm{p}>0.05)$, indicating the absence of anemia and normal globular volume. This reinforces the importance of the measurement of EPG; this is a quantitative method and does not depend on the subjective interpretation of the results.
\end{abstract}

Key words: Anthelmintic effectiveness. Cratylia spp. Gastrointestinal helminths. Small ruminants.

\section{Resumo}

Os nematódeos gastrointestinais são considerados um dos problemas sanitários mais importantes dos ruminantes no mundo, seja em infecções isoladas ou atuando com outros patógenos, são responsáveis por severas perdas econômicas relacionadas à produção animal. $\mathrm{O}$ controle dos endoparasitas em pequenos ruminantes normalmente é feito por meio de drogas anti-helmínticas. No entanto, determinadas cepas de endoparasitos são resistentes a esses fármacos. A suplementação da dieta com alimentos ricos em proteína é uma estratégia para reduzir o impacto negativo das parasitoses gastrointestinais. Cratylia

\footnotetext{
${ }^{1}$ Prof. Pesquisador, Empresa de Pesquisa Agropecuária de Minas Gerais, EPAMIG, Instituto Técnico de Agropecuária e Cooperativismo, ITAC, Campo Experimental de Pitangui, CEPI, Zona Rural, Pitangui, MG, Brasil. E-mail: manoelsilva@, epamig.br

2 Prof. Titular, Universidade Federal de Viçosa, DVT/UFV, Viçosa, MG, Brasil. E-mail: jvictor@ufv.br

${ }^{3}$ Discente do Curso de Doutorado, Programa de Pós-Graduação em Biologia Celular e Estrutural, DBG/UFV, Viçosa, MG, Brasil. E-mail: deosilveira@yahoo.com.br

4 Discente do Curso de Doutorado, Programa de Pós-Graduação em Medicina Veterinária, DVT/UFV, Viçosa, MG, Brasil. E-mail: lorendane@gmail.com

5 Prof. Associado, Departamento de Medicina Veterinária, Universidade Federal de Juiz de Fora, UFJF, Juiz de Fora, MG, Brasil. E-mail: raul.rio@ufjf.edu.br

* Author for correspondence
} 
argentea tem efeito anti-helmíntico, além de outras características que favorecem seu uso como suplemento para alimentação animal. No presente estudo, borregas cruzadas foram subdivididas em grupos homogêneos e alimentadas com C. argentea (G1), C. argentea mais Brachiaria spp. (G2) ou apenas Brachiaria spp. (G3). Os animais do grupo G1 apresentaram menor valor médio de ovos por grama de fezes $(\mathrm{OPG})$ aos 42 dias $(\mathrm{p}<0,05)$ e sua contagem média foi dez vezes mais baixa que a do controle no último período de tempo avaliado (56 dias). Os animais apresentaram aumento linear do ganho de peso e aqueles do grupo G1 apresentaram o maior ganho. O escore FAMACHA ${ }^{\circledR}$ mostrou pouca variação durante o experimento $(\mathrm{p}>0,05)$, indicando ausência de anemia e volume globular normal. Isso reforça a importância da avaliação por OPG, que é um método quantitativo e não depende de interpretação subjetiva de resultados.

Palavras-chave: Eficácia anti-helmíntica. Cratylia sp. Helmintos gastrintestinais. Pequenos ruminantes.

\section{Introduction}

Gastrointestinal nematodes (GINs) are one of the most important causes of sanitary problems in ruminants globally (AMARANTE; AMARANTE, 2016; ESCOBAR, 2016; ESTEBANBALLESTEROS et al., 2017; MOLENTO et al., 2016). Haemonchus, Trichostrongylus, and Oesophagostomum are the main genera that cause GIN infections in small ruminants; they are responsible for economic losses because they reduce productivity and increase mortality. They may parasitize alone or may be concomitant with other pathogens. The presence of Haemonchus contortus in mixed infections adversely affects the health of animals because it is hematophagous and can cause anemia, hypoproteinemia, anorexia, weight loss, reduced meat and milk production, and mortality (ACHI et al., 2003; EMERY et al., 2016; SALGADO; SANTOS, 2016; TARIQ, 2015).

Endoparasites in small ruminants are usually controlled with synthetic anti-helminthic drugs. However, apart from concerns arising from drugresistant strains, there is an increasing demand for residue-free foods that are ecologically sound, green, and organic (ESTEBAN-BALLESTEROS et al., 2017; LEARMOUNT et al., 2016; SALGADO; SANTOS, 2016).

One strategy to improve an animal's body condition score is to reduce the negative impact of gastrointestinal parasites by supplementing the diet with protein-rich foods (HOSTE et al., 2016). This can be achieved by supplying commercial feeds - such as corn silage and soybeans - and by encouraging native plants to act as protein banks, especially in regions lacking financial resources where the soil does not allow the cultivation of crops.

Some regions of Brazil are characterized by low water availability and the irregular distribution of rainfall. The availability of water in the soil is further reduced by evaporation at raised temperatures; this impairs the growth of plants and reduces the nutritional quality of the forage (LUZ et al., 2015). Choosing plants with high nutritional value that are resistant to a semi-arid climate is important for maintaining production at acceptable levels (ANDRADE et al., 2010).

Cratylia argentea (Desv.) Kuntze (Fabaceae) is a perennial shrub-shaped legume that has a high yield and nutritional value, even in acid soils with low moisture content. These are characteristics that favor its use as an animal feed supplement during the dry season in semi-arid regions (ARGEL; LASCANO, 1998; LUZ et al., 2015). In addition to its nutritional qualities, the anthelmintic effects of Cratylia spp. have been reported empirically by producers of small ruminants in the interior of Brazil (ALBUQUERQUE et al., 2007), and by researchers in vitro (MENDONÇA-LIMA et al., 2016; MENEZES et al., 1991; SILVA et al., 2017). Thus, the aim of the present work was to evaluate for the first time the in vivo effectiveness of $C$. argentea on gastrointestinal nematodes of sheep in a "protein bank" type management system. 


\section{Material and Methods}

\section{Biosafety and ethics in animal use}

All animal-handling procedures were carried out in accordance with the Ethical Principles of Animal Experimentation adopted by the Brazilian College of Veterinary Medicine and the Brazilian College of Animal Experimentation: COBEA. The whole procedure was approved by the Committee on Ethics in the Use of Animals of the Agricultural Research Company of Minas Gerais (EPAMIG), under Protocol Number 04/2016.

\section{Local}

The experiment was carried out at the Experimental Field of Pitangui (CEPI) belonging to the Agricultural Research Company of Minas Gerais (EPAMIG) in the municipality of Pitangui, MG; latitude $19^{\circ} 40^{\prime} 58^{\prime \prime} \mathrm{S}$, longitude $44^{\circ} 53^{\prime} 25^{\prime \prime} \mathrm{W}$, and 709 meters above sea level.

\section{Animals and handling}

Thirty female crossbreed lambs (1/2 Dorper), reared on a slatted and suspended floor and weaned at 60 days of age, which had never been treated previously with an anthelmintic, were subdivided into three homogeneous groups $(\mathrm{p}>0.05)$ at $151.4 \pm$ 12.7 days old according to mean body weight (BW) (G1 31.9 $\pm 5.2 \mathrm{~kg}^{-1} \mathrm{BW}$; G2 $31.7 \pm 5.5 \mathrm{~kg}^{-1} \mathrm{BW}$; G3 $\left.31.8 \pm 5.7 \mathrm{~kg}^{-1} \mathrm{BW}\right)$, and elimination of eggs per gram of feces (EPG) (G1 30.0 448.3 EPG; G2 20.0 \pm 42.2 EPG; G3 50.0 \pm 85.0 EPG). Group 1 (G1) comprised animals fed on a paddock of 1 animal unit (AU)/hectare (2.4 acres) formed by $C$. argentea as a "protein bank" (vouchers are deposited in the PAMG/EPAMIG Herbarium under registry 57971). Group 2 (G2) comprised animals fed on $C$. argentea as a "protein bank" plus Brachiaria spp. Group 3 (G3) comprised animals fed only Brachiaria spp. In the period from $08 \mathrm{~h} 00$ to $10 \mathrm{~h} 00$, the animals in G1 and G2 were separated by a picket formed by the legume $C$. argentea. After grazing in a "protein bank" the animals in G1 were moved to a covered sheepfold and supplemented with sugarcane ad libitum corrected with $0.85 \%$ urea and $0.15 \%$ ammonium sulfate. After grazing in a "protein bank", the animals in G2 were moved to a paddock of 1 AU/hectare formed by Brachiaria spp., where they remained until $15 \mathrm{~h} 00$. The G3 animals remained on the paddock formed by Brachiaria spp. all day, respecting the stocking rate adopted. In the afternoon, the G2 and G3 animals were moved to the covered sheepfold, divided into experimental groups, supplemented with 500 grams per animal per day of concentrate with $16 \%$ crude protein $(\mathrm{CP})$ and $80 \%$ total digestible nutrients (TDN), $200 \mathrm{~g}$ of citrus pulp, and pelleted soybean shells, and kept until the morning of the following day.

\section{Zootechnical, clinical, and laboratory evaluations}

The experiment was carried out over 56 days. Every 14 days, the animals were weighed individually on a mechanical scale and a fecal sample was collected directly from the rectal ampoule for coproparasitological investigations. The animals were individually evaluated by counting the EPG and oocysts per gram of feces (OoPG) according to the method described by Roberts and O'Sullivan (1950) with a few modifications (UENO; GONÇALVES, 1998). Coprocultures were carried out for the recovery and identification of infective larvae $\left(\mathrm{L}_{3}\right)$ according to the method described by Keith (1953). The color of the ocular mucosa (FAMACHA ${ }^{\circledR}$ ) of the experimental animals was determined at the time of weighing and stool collection (REYNECKE et al., 2011; RILEY; VAN WYK, 2009).

\section{Meteorological data}

The average temperatures and daily rainfalls were evaluated using a thermometer and a rain gauge, respectively, installed near the animal management center. 


\section{Statistical analyses}

The weight, FAMACHA ${ }^{\circledR}$ score, EPG, and OoPG after logarithmic transformation $(\log \mathrm{x}+1)$ were subjected to analysis of variance (ANOVA). When there was variation in the results $(p<0.05)$, the Tukey test was used to compare means with the aid of BioEstat 5.0 software (AYRES et al., 2003). A significance level of $95 \%$ was applied in all statistical tests.

\section{Results and Discussion}

Tropical and subtropical climates with continually high temperatures support the larval development of endoparasites. The prevalence of such parasites in grazing animals is therefore particularly high in the tropical zones of both hemispheres (BESIER et al., 2016). During the experimental period, there was a regular distribution of rainfall totaling 304 $\mathrm{mm}^{3}$ and a mean temperature of $23.7^{\circ} \mathrm{C}(18.1-$ $31.0^{\circ} \mathrm{C}$ ). When associated with poor pastures and/ or deficient feeding, these environmental conditions encourage the development of GIN larvae, reducing the productivity of the livestock, and may even lead to the death of untreated animals (LIMA, 1989).

According to Amarante and Amarante (2016), the number of nematode eggs in samples of feces and the morphological identification of third instar larvae from fecal cultures are reliable and representative ways of measuring the magnitude of the parasite burden, with satisfactory results for the diagnosis of GIN infections in ruminants. In the present study, the experimental animals fed with $C$. argentea $(\mathrm{G} 1)$ had a reduced EPG from Day $42(\mathrm{p}<0.05)$ compared with those fed with $C$. argentea plus Brachiaria spp. (G2) or Brachiaria spp. only (G3) (Figure 1). The group G1 animals had average egg counts at least ten times lower than those of the other groups in the last evaluated period of time. The impact of C. argentea $(\mathrm{G} 1)$ on egg count reduction recorded from the sixth week of treatment is in agreement with the literature. Van Zyl et al. (2017) observed substantially lower fecal egg counts in Merino ewes fed with another legume, Lespedeza cuneata, after 35 days. Mendonça-Lima et al. (2016) reported a significant reduction in oviposition $(61.1 \%)$ in goats treated with an aqueous extract of Cratylia mollis leaves after 30 days.

There are few detailed publications on the bromatological analysis of Cratylia argentea. However, it probably comprises a moderate level of condensed tannin (HESS et al., 2004) and approximately $19.10 \%$ crude protein (CASTILLOGALLEGOS et al., 2013). Therefore, it is reasonable to assume that both protein supplementation and tannin consumption from $C$. argentea (GI) may have influenced the host's ability to fight endoparasites. Plants containing condensed tannins or others bioactive compounds can be used as an alternative to conventional therapeutics to control helminths, and can be used concomitantly with chemotherapy to reduce the consumption of conventional anthelmintic drugs (SANDOVAL-CASTRO et al., 2012; YOSHIHARA et al., 2013). 
Figure 1. Mean egg count per gram of feces (EPG) quantified by the McMaster technique in female sheep fed with Cratylia argentea (G1), C. argentea plus Brachiaria spp. (G2), or Brachiaria spp. only (G3) over 56 days at 0, 14, 28, 42, and 56 days.

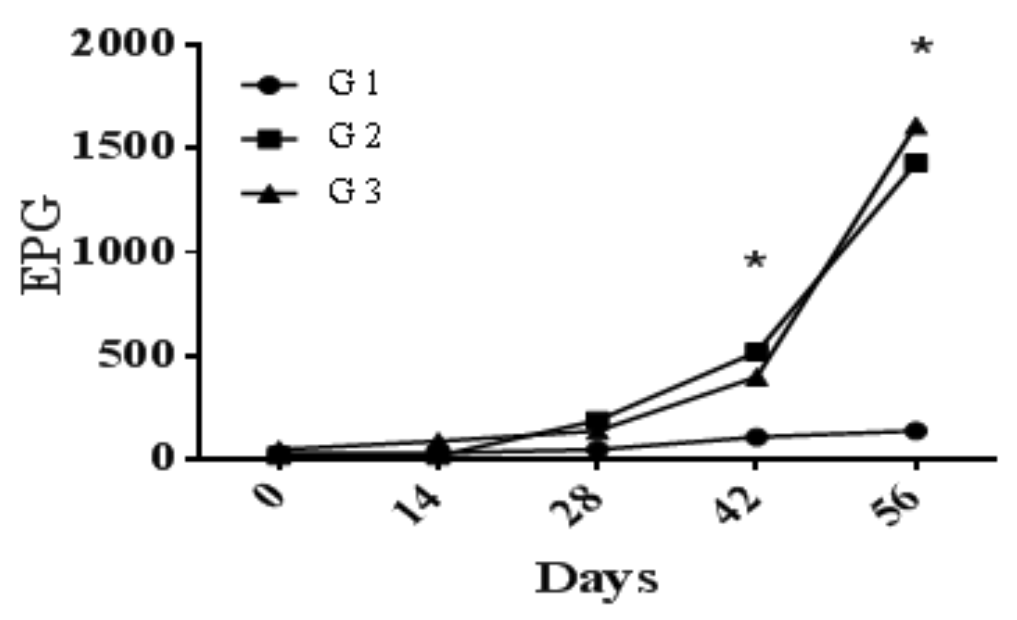

Silva et al. (2017) suggest that $C$. argentea extract mainly obtained from pods/ground seeds has potential for the control of the early stages of gastrointestinal nematodes. Menezes et al. (1991) showed in vitro that Cratylia floribunda reduced by $15.5,64.9$, and $99.7 \%$, respectively, the hatchability of eggs in coproculture on dosages of 50, 300, and $500 \mathrm{mg}$ per gram of feces. Implementation of a combinational approach with bioactive compounds and drugs can minimize the evolution of multidrug resistance, prolonging the efficacy of the drugs.

Although there were no statistically significant differences in weight between the groups during the experimental period $(\mathrm{p}>0.05)$, we did observe a linear weight gain in the animals (average daily gain (ADG): G1 $0.175 \mathrm{~kg}$ day $^{-1}$; G2 $0.189 \mathrm{~kg} \mathrm{day}^{-1}$; G3 $0.171 \mathrm{~kg} \mathrm{day}^{-1}$ ), and the animals in G1 exhibited greater weight gain in three of the five time-periods evaluated $(+14,+28$, and +42 day) when compared with the other groups (Figure 2). There was a statistically significant difference from time +42 to time " 0 " days (G1), and from +56 to +14 days (G2 and G3) (Figure 2). According to Besier et al. (2016), chronic forms of hemonchosis are characterized by weight loss or poor weight gain, general ill health, and a degree of anemia in some individuals.

Figure 2. Mean body weight (BW) of female sheep fed with Cratylia argentea (G1), C. argentea plus Brachiaria spp. (G2), or Brachiaria spp. only (G3) over 56 days at $0,14,28,42$, and 56 days.

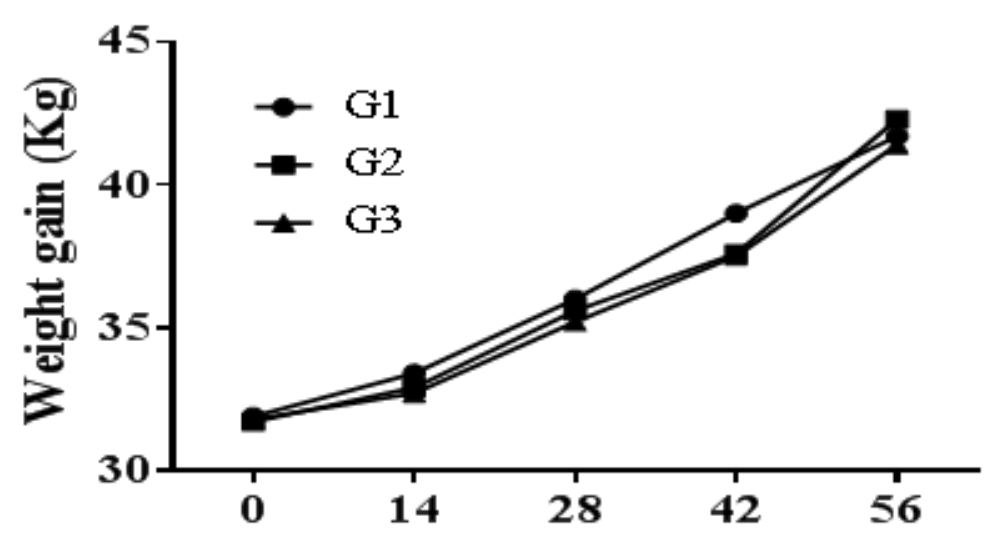


The FAMACHA ${ }^{\circledR}$ score applies to infections caused by hematophagous helminths, especially Haemonchus sp. (VAN WYK, 2008). For this reason, we used the technique as a means of evaluating the efficacy of $C$. argentea, because Haemonchus was predominant (91\% Haemonchus sp. and 9\% Strongyloides sp.) in the coprocultures from all groups carried out in the present work and also in previous observations made at the same location. There were few variations in the coloration of the ocular mucosa of the animals (FAMACHA ${ }^{\circledR}$ ) during the experiment $(\mathrm{p}>0.05)$. The animals in all three groups exhibited mucosal coloration below grade three, indicating the absence of anemia, and normal packed cell volume (PCV) within the acceptable parameters (Figure 3). Although the cocultures showed a predominance of Haemonchus sp. (91\%), the absence of a statistical difference in the FAMACHA ${ }^{\circledR}$ score can be explained by the high protein content of the diet, which can increase the resistance and resilience of the animals to parasitism (HOSTE et al., 2016). In this sense, we emphasize the technical importance of EPG, which is a quantitative parameter and is independent of the subjective evaluation of results (AMARANTE; AMARANTE, 2016) compared with the FAMACHA ${ }^{\circledR}$ score. Under tropical conditions, $H$. contortus is usually one of the predominant GINs, and often occurs with Trichostrongylus colubriformis and/or Oesophagostomum columbianum (COSTA et al., 2017; FABIYI, 1987; HOSTE et al., 2016; MOLENTO et al., 2016; SANTOS et al., 2015). Therefore, an evaluation method that identifies hematophagous and non-hematophagous parasites is required in such circumstances.

Figure 3. Mean oocysts count per gram of feces (OoPG) quantified by the McMaster technique in female sheep fed with Cratylia argentea (G1), C. argentea plus Brachiaria spp. (G2), or Brachiaria spp. only (G3) over 56 days at 0, $14,28,42$, and 56 days.

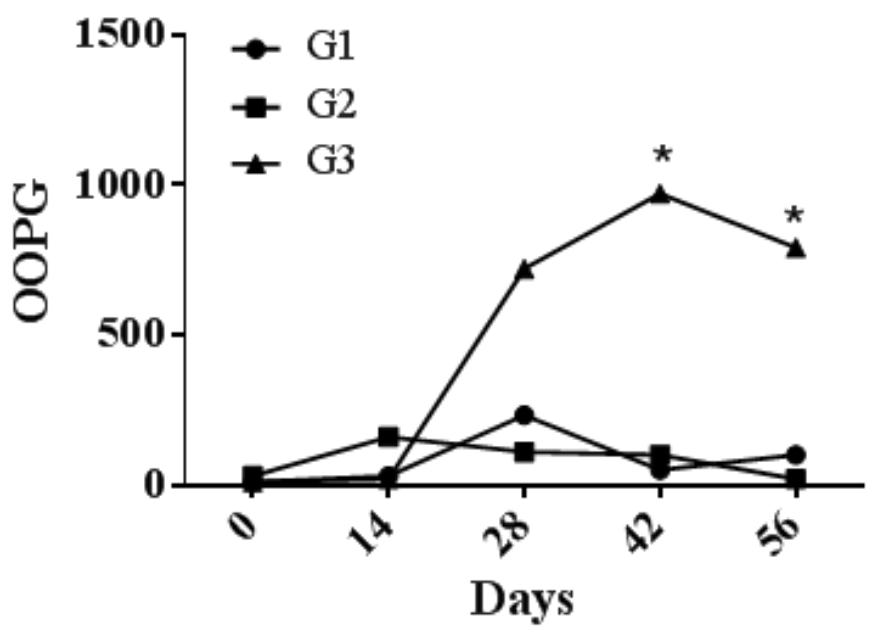

From Day +56 , the animals fed only with Brachiaria spp. exhibited higher numbers of oocysts eliminated per gram of feces (OoPG) than those in groups G1 and G2 (p<0.005) (Figure 4). According to Adeppa et al. (2016), coccidiosis is one of the main factors responsible for high mortality in sheep, particularly among young stock. We believe that the proposed picket and/or management conditions may have facilitated a higher rate of infection of Eimeria spp. in the G3 animals. However, there are currently no reports in the literature on the effect of $C$. argentea on coccidian agents. Moreover, it is 
important to consider that the G1 animals spent less time grazing than the G2 and G3 animals, which may have affected their EPG and OoPG values. Therefore, additional studies are required to confirm these results.

Figure 4. FAMACHA ${ }^{\circledR}$ score of female sheep fed with Cratylia argentea (G1), C. argentea plus Brachiaria spp. (G2), or Brachiaria spp. only (G3) over 56 days at $0,14,28,42$, and 56 days.

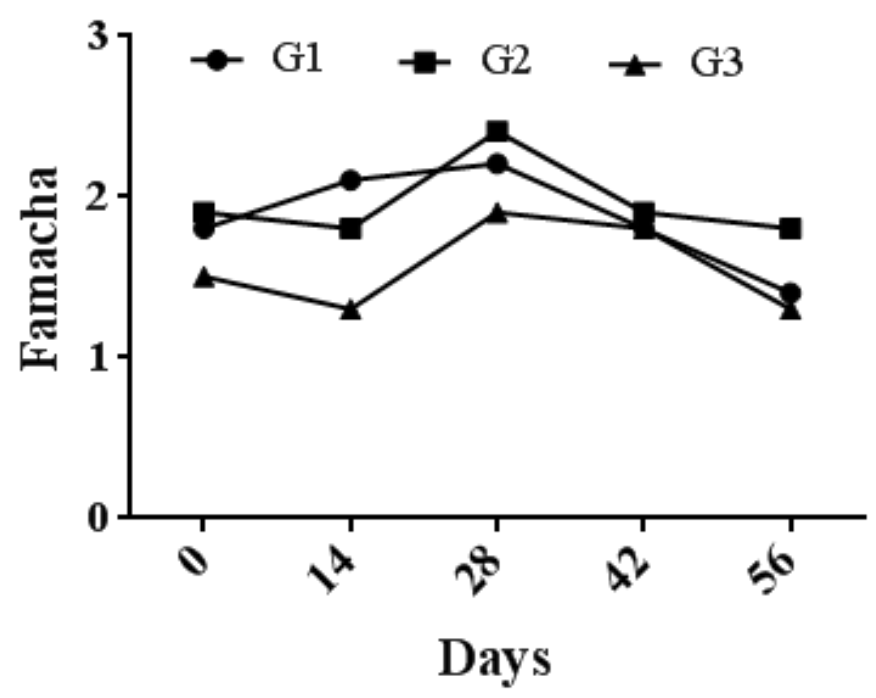

\section{Conclusions}

When handled in a "protein bank" system, Cratylia argentea can be strategically offered to animals and advantageously incorporated into integral plague control programs with the potential to control gastrointestinal nematodes. However, further studies are needed to identify the active components of the plant, and to determine management methods for its use as an alternative method of controlling and preventing the propagation of anthelminticresistant parasitic strains.

\section{Acknowledgments}

The authors are grateful to the National Council for Scientific and Technological Development (CNPq), the State of Minas Gerais Research Foundation (FAPEMIG), the Minas Gerais Agricultural Research Company (EPAMIG), and the Federal University of Juiz de Fora (UFJF) for providing logistical and financial support.

\section{References}

ACHI, Y. L.; ZINSSTAG, J.; YAO, K.; YEO, N.; DORCHIES, P.; JACQUIET, P. Host specificity of Haemonchus spp. for domestic ruminants in the savanna in northern Ivory Coast. Veterinary Parasitology, Amsterdam, v. 116, n. 2, p. 151-158, 2003.

ADEPPA, J.; JAVAREGOWDA, A. K.; KRISHNAMURTHY, C. M. An outbreak of coccidiosis in a stall fed sheep farm and its treatment in Shimoga Region, Karnataka. Indian Veterinary Journal, Madras, v. 93, n. 3, p. 17-19, 2016.

ALBUQUERQUE, U. P.; MUNIZ DE MEDEIROS, P.; ALMEIDA, A. L. de; MONTEIRO, J. M.; LINS NETO, E. M. de F.; MELO, J. G. de; SANTOS, J. P. dos. Medicinal plants of the caatinga (semi-arid) vegetation of NE Brazil: a quantitative approach. Journal of Ethnopharmacology, Limerick, v. 114, n. 3, p. 325-354, 2007.

AMARANTE, A. F. T.; AMARANTE, M. R. V. Advances in the diagnosis of the gastrointestinal nematode infections in ruminants. Brazilian Journal of Veterinary Research and Animal Science, São Paulo, v. 53, n. 2, p. 127-137, 2016. 
ANDRADE, A. P.; COSTA, R. G.; SANTOS, E. M.; SILVA, D. S. Animal production in the semiarid: the challenge of forage avalability, in amount and with quality, during the dry season. Tecnologia \& Ciência Agropecuária, João Pessoa, v. 4, n. 4, p. 1-14, 2010.

ARGEL, P. J.; LASCANO, C. E. Cratylia argentea (Desvaux) O. Kuntze: una nueva leguminosa arbustiva para suelos ácidos en zonas subhúmedas tropicales. Pasturas Tropicales, Cali, v. 20, n. 1, p. 37-43, 1998.

AYRES, M.; AYRES, J. R. M.; AYRES, D. L.; SANTOS, A. A. S. Aplicações estatísticas nas áreas de ciências biológicas. Belém: Sociedade Civil Mamirauá/CNPq, 2003. $290 \mathrm{p}$.

BESIER, R. B.; KAHN, L. P.; SARGISON, N. D.; VAN WYK, J. A. The pathophysiology, ecology and epidemiology of Haemonchus contortus infection in small ruminants. Advances in Parasitology, London, v. 93, n. 3, p. 95-143, 2016.

CASTILLO-GALLEGOS, E.; ESTRADA-FLORES, J. G.; VALLES-DE LA MORA, B.; CASTELÁNORTEGA, O. A.; OCAÑA-ZAVALETA, E.; JARILLORODRÍGUEZ, J. Total dry matter yield and nutritive quality of leaves and young stems of four Cratylia argentea accessions in the humid tropics of Veracruz, Mexico. Avances en Investigación Agropecuaria, Colima, v. 17, n. 1, p. 79-94, 2013.

COSTA, P. T.; COSTA, R. T.; MENDONÇA, G.; VAZ, R. Z. Comparative anthelminthic efficacy of nitroxynil, levamisole, closantel, moxidectin and fenbendazole on parasite control in sheep. Boletim de Indústria Animal, Nova Odessa, v. 74, n. 1, p. 72-78, 2017.

EMERY, D. L.; HUNT, P. W.; LE JAMBRE, L. F. Haemonchus contortus: the then and now, and where to from here? International Journal for Parasitology, New York, v. 46, n. 12, p. 755-769, 2016.

ESCOBAR, E. N. A review on the use of herbs and spices as alternative compounds to manage helminthosis in small ruminants. Journal of Livestock Science, Bikaner, v. 7, p. 244-249, 2016.

ESTEBAN-BALLESTEROS, M.; ROJO-VÁZQUEZ, F. A.; SKUCE, P. J.; MELVILLE, L.; GONZÁLEZLANZA， C.; MARTÍNEZ-VALLADARES, M. Quantification of resistant alleles in the $\beta$-tubulin gene of field strains of gastrointestinal nematodes and their relation with the faecal egg count reduction test. $B M C$ Veterinary Research, London, v. 13, n. 1, p. 71, 2017.

FABIYI, J. P. Production losses and control of helminths in ruminants of tropical regions. International Journal for Parasitology, New York, v. 17, n. 2, p. 435-442, 1987.
HESS, H. D.; BEURET, R. A.; LÖTSCHER, M.; HINDRICHSEN， I. K.; MACHMÜLLER, A.; CARULLA, J. E.; LASCANO, C. E.; KREUZER, M. Ruminal fermentation, methanogenesis and nitrogen utilization of sheep receiving tropical grass hayconcentrate diets offered with Sapindus saponaria fruits and Cratylia argentea foliage. Animal Science, Cambridge, v. 79, n. 1, p. 177-189, 2004.

HOSTE, H.; TORRES-ACOSTA, J. F.; QUIJADA, J.; CHAN-PEREZ, I.; DAKHEEL, M. M.; KOMMURU, D. S.; MUELER-HARVEY, I.; TERRILL, T. H. Interactions between nutrition and infections with Haemonchus contortus and related gastrointestinal nematodes in small ruminants. Advances in Parasitology, London, v. 93, n. 3, p. 239-351, 2016.

KEITH, R. K. The differentiation of the infective larvae of some common nematode. Australian Journal of Zoology, Melbourne, v. 1, n. 2, p. 223-235, 1953.

LEARMOUNT, J.;STEPHENS, N.;BOUGHTFLOWER, V.; BARRECHEGUREN, A.; RICKELL, K. The development of anthelmintic resistance with best practice control of nematodes on commercial sheep farms in the UK. Veterinary Parasitology, Amsterdam, v. 229, n. 16, p. 9-14, 2016.

LIMA, W. S. Dinâmica de populações de nematoides parasitos gastrointestinais em bovinos de corte: alguns aspectos da relação parasito-hospedeiro e do comportamento de estádios de vida livre na região do Vale do Rio Doce, MG, Brasil. 1989. Tese (Doutorado em Parasitologia Veterinária) - Instituto de Ciências Biológicas, Universidade Federal de Minas Gerais, Belo Horizonte.

LUZ, G. A.; GOMES, S. O.; ARAUJO NETO, R. B.; NASCIMENTO, M. S.; LIMA, P. S. Molecular characterization of accessions of Cratylia argentea (Camaratuba) using ISSR markers. Genetics and Molecular Research, Ribeirão Preto, v. 14, n. 4, p. 1524215248, 2015.

MENDONÇA-LIMA, F. W.; SANTOS, R. B.; SANTOS, L. C.; ZACHARIAS, F.; DAVID, J. M.; DAVID, J. P.; LÓPEZ, J. A. Anthelmintic activity of Cratylia mollis leaves against gastrointestinal nematodes in goats. Revista Brasileira de Saúde e Produção Animal, Salvador, v. 17, n. 4, p. 753-762, 2016.

MENEZES, R. C. A. A.; VIEIRA, L. da S.; CAVALCANTE, A. C. R.; CAVADA, B. S.; OLIVEIRA, J. T. A.; MOREIRA, R. A. Estudos preliminares in vitro da atividade ovicida de folhas e sementes de quatro leguminosas sobre Haemonchus contortus de caprinos. Revista Brasileira de Parasitologia Veterinária, Jaboticabal, v. 1, p. 37, 1991. 
MOLENTO, M. B.; BUZATTI, A.; SPRENGER, L. K. Pasture larval count as a supporting method for parasite epidemiology, population dynamic and control in ruminants. Livestock Science, Amsterdam, v. 192, n. 2, p. 48-54, 2016.

REYNECKE, D. P.; VAN WYK, J. A.; GUMMOW, B.; DORNY, P.; BOOMKER, J. Validation of the FAMACHAC eye colour chart using sensitivity/ specificity analysis on two South African sheep farms. Veterinary Parasitology, Amsterdam, v. 177, n. 3-4, p. 203-211, 2011.

RILEY, D. G.; VAN WYK, J. A. Genetic parameters for FAMACHA score and related traits for host resistance/ resilience and production at differing severities of worm challenge in a Merino flock in South Africa. Veterinary Parasitology, Amsterdam, v. 164, n. 1, p. 44-52, 2009.

ROBERTS, F. H. S.; O’SULLIVAN, P. J. Methods for egg counts and larval cultures for Strongyles infesting the gastrointestinal tract of cattle. Australian Journal of Agricultural Research, Melbourne, v. 1, n. 1, p. 99-102, 1950.

SALGADO, J. A.; SANTOS, C. de P. Overview of anthelmintic resistance of gastrointestinal nematodes of small ruminants in Brazil. Revista Brasileira de Parasitologia Veterinária, Jaboticabal, v. 25, n. 1, p. 3-17, 2016.

SANDOVAL-CASTRO, C. A.; TORRES-ACOSTA, J. F. J.; HOSTE, H.; SALEM, A. Z. M.; CHAN-PÉREZ, J. I. Using plant bioactive materials to control gastrointestinal tract helminths in livestock. Animal Feed Science and Technology, Amsterdam, v. 176, n. 1-4, p. 192-201, 2012.
SANTOS, R. A.; BRITO, J. A.; FERREIRA, R.; BISCARDE, C. E. A.; SILVA, S. M.; RIBEIRO, R. $\mathrm{R}$. Fecal monitoring of ruminants in Cruz das Almas. Recôncavo region of Bahia, Brazil. Parasitología Latinoamericana, Santiago, v. 64, n. 2, p. 15-22, 2015.

SILVA, M. E.; ARAÚJO, J. V.; SILVA, J.A.; CARVALHO, L. M.; CHAGAS, E.; RIBEIRO, R. R. Anthelmintic efficacy of Cratylia argentea (Desv.) Kuntze against the gastrointestinal nematodes of sheep. Semina: Ciências Agrárias, Londrina, v. 38, n. 5, p. 3105-3112, 2017.

TARIQ, K. A. A review of the epidemiology and control of gastrointestinal nematode infections of small ruminants. Proceedings of the National Academy of Sciences, India. Section B: Biological Science. Allahabad, v. 85, n. 2, p. 693-703, 2015.

UENO, H.; GONÇALVES, P. C. Manual para diagnóstico das helmintoses de ruminantes. 4. ed. Tokio: Japan International Cooperation Agency, 1998. 143 p.

VAN WYK, J. A. Production trials involving use of the FAMACHAC system for haemonchosis in sheep: preliminary results. Onderstepoort Journal of Veterinary Research, Durbanville, v. 75, n. 4, p. 331-345, 2008.

VAN ZYL, E. A.; BOTHA, F. S.; ELOFF, K. J. N.; MSUNTSHA, P. P.; OOSTHUIZEN, P. A.; STEVENS, C. The use of Lespedeza cuneate for natural control of gastrointestinal nematodes in Merino sheep. Onderstepoort Journal of Veterinary Research, Durbanville, v. 84, n. 1, p. e1-e7, 2017.

YOSHIHARA, E.; MINHO, A. P.; YAMAMURA, M. H. Anthelmintic effect of condensed tannins in gastrointestinal nematodes of sheep (Ovis aries). Semina: Ciências Agrárias, Londrina, v. 34, n. 6, p. 3935-3950, 2013. 
